\title{
Applicability of EU Legislative Standards against Discrimination for Non-EU Countries
}

\author{
Dr. H. Esra Arcan \\ Istanbul University, Turkey \\ Email: earcan2000@yahoo.com, arcan@istanbul.edu.tr
}

\section{Doi:10.5901/mjss.2014.v5n1p11}

\section{Abstract}

Segregation, lynching, slavery are the part of humankind's history that is the result of discrimination policies. Today, diversity of societies is a reality of our world and the integration of diversity is essential for peace in plural societies. Integration of diversity could only be possible if this diversity is recognized and cultural pluralism is promoted by state policies which is possible only if humankind overcome discrimination. Forming legislative standards against discrimination is an important part of fighting against discrimination as state policy. Therefore, this study scrutinizes the concept of discrimination as a case of Turkey and Europe. Then, the study examines the legislative standards of European Union against discrimination as a pioneering effort and questions implementation of legislative standards in European Countries. The study concludes that, legislative standards against discrimination are necessary and European Union has pioneered in this field. As a matter of fact European societies and governmental bodies still has problems implementing and need a mentality change yet non-European countries can be inspired by principle and spirit of anti-discrimination legislative standards.

Keywords: Discrimination, Ethnic conflict, EU Anti-discrimination legislative standards, Turkey,

\section{Discrimination}

\author{
Strange Fruit \\ Southern trees bear strange fruit \\ Blood on the leaves \\ Blood at the root \\ Black bodies swinging in the southern breeze \\ Strange fruit hanging from the poplar trees \\ Pastoral scene of the gallant south \\ The bulging eyes and the twisted mouth \\ The scent of magnolia sweet and fresh \\ Then the sudden smell of burning flesh \\ Here is a fruit for the crows to pluck \\ For the rain to gather \\ For the wind to suck \\ For the sun to rot \\ For the tree to drop \\ Here is a strange and bitter crop
}

Strange Fruit, a uniquely beautiful song that originally sung and most famously performed by Billie Holiday, began as a poem about the lynching of a black man written by Meeropol, a Jewish schoolteacher from the Bronx, New York. Meeropol later said that he had been inspired by Lawrence Beitler's photograph of the lynching of Black Africans, Thomas Shipp and Abraham Smith who were hanged on the branches of a tree. The "strange fruit" in thesong, refers to the bodies of African American men hanged during the lynching. They contrast the pastoral scenes of the South with the ugliness of racist violence. The song was ultimately became the anthem of the anti-lynching movement and have planted the seeds for the Civil Rights Movement in the U.S.

Lynching now seems too strange to us but when the first time the song was performed, it was found so challenging to the establishment that Columbia Records refused to record the song. The year was 1939 when institutionalized segregation and discrimination was used to be a part of daily life in the U.S. Why do some people think that "other" people deserve suffering just because of their skin color, ethnic origin, language, religion or their life style? What kind of mechanism blinds our conscious? Who would construct this kind of a brutal social structure? Today, decades after the 
declaration of Convention on the Elimination of All Forms of Discrimination, similar questions are being echoed by a white woman's statement from Cape Town, South Africa; "I realize that I lived a very sheltered and privileged life. I feel unable to cope with the radical changes that are taking place in South Africa. I feel guilty about that and try to make amends in my small circle of interaction with people of colour."(Nascimento and Nascimento, 2001; 89)

Unfortunately, as it can be seen in the South African women's statement, discrimination and its cognitive and psychological effects are still functioning in a powerful way in our daily lives. However, since 1965, Convention on the Elimination of All Forms of Discrimination has defined discrimination as follows; "any distinction, exclusion or preference based on race, colour, descent or national or ethnic origin which has the purpose or effect of nullifying or impairing the recognition, enjoyment exercise on an equal footing, of human rights and fundamental freedoms in the political, economical, social, cultural or any other fields of public life" and has condemned it. ${ }^{1}$

The role that discrimination plays in a society is explained in the Article 2 (2) of the Declaration on Race and Racial Prejudice (1978) which defines racism as the strictest form of discrimination;

"Racism includes racist ideologies, prejudiced attitudes, discriminatory behaviour, structural arrangements and institutionalized practices resulting in racial inequality as well as the fallacious notion that discriminatory relations between groups are morally and scientifically justifiable; it is reflected in discriminatory provisions in legislation or regulations and discriminatory practices as well as in anti-social beliefs and acts; it hinders the development of its victim, perverts those who practise it, divides nations internally, impedes international co-operation and gives rise to political tensions between peoples; it is contrary to the fundamental principles of international law and, consequently, seriously, disturbs international peace and security". (UNESCO, 1999; 110)

Furthermore, Article 2 (3) of the Declaration on Race and Racial Prejudice states that "Racial prejudice, historically linked with inequalities in power, reinforced by economic and social differences between individuals and groups, and still seeking today to justify such inequalities, is totally without justification". Discriminatory practices of the dominant ethnic groups as the main reasons for conflict needs special attention, hence cultural, social, political and economic discrimination should be examined at following levels: psychological, cultural, economic, and political.

\subsection{Cultural and Social Discrimination: Recognition and Representation of Ethnic Minorities}

Roger Brown (1986: 533) proposes that intergroup conflicts require "three legs of a stool";(1) real differences in interests, resources, power, and so on between the two parties, (2) stereotypes, or more general negative schemas or expectations, and (3) perceived injustices. In discriminatory societies ethnic relations and encounters are in confrontational character in which, stigmatization, demonization, prejudices, stereotypes, and similar cognitive mechanisms of discrimination are common. Mechanisms that are controlled by the dominant "superior" power such as the education system, the media are manipulated to produce a society that evidence the apparentsuperiority of the dominants, meanwhile creating a distorted representation of the subordinate ethnic group. Distorted representations cause miss-recognition or non-recognition of minority groups. Charles Taylor (1994: 25) explains the importance of recognition from the psychological perspective and brings forward miss-non recognition as a matter of individual's selfrealization: "our identity is partly shaped by recognition or its absence, often by the misrecognition of others, and so a person or group of people can suffer real damage, real distortion, if the people or society around them mirror back to them a confining or demeaning or contemptible picture of themselves. Non-recognition or misrecognition can inflict harm; can be a form of oppression, imprisoning someone in afalse, distorted, and reduced mode of being."By doing so, socialandcultural discrimination and exclusion of some ethnic minorities become possible and legitimate at cognitive, social and cultural levels. Fraser (1998: 35) draws attention to another function of misrecognition as a status injury from the social relation perspective and suggests that "To be misrecognized, on this view, is not simply to be thought ill of, looked down on, or devalued in others' conscious attitudes or mental beliefs. It is rather to be denied the status of a full partner in social interaction and prevented from participating as a peer in social life as a consequence of institutionalized patterns of cultural value that constitute one as comparatively unworthy of respect or esteem." As explained by Fraser, recognition politics function as a tool of legitimizing the discrimination both at an individual and a social level.

It is known that how rituals and symbolic representations operate through a social process and cultural media. In doing so, it creates ethnic or national imagined or invented boundaries as underscored by the constructivists' studies. Also it was mentioned that Hobsbawm(1983: 1)defined invention of tradition as "a set of practices, normally governed by

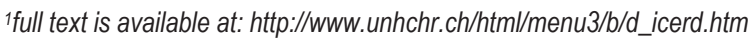


overtly or tacitly accepted rules and of a ritual or symbolic nature, which seek to inculcate certain values and norms of behaviour by repetition, which automatically implies continuity with the past". Some examples from my own childhood can explain how a child learns who he/she is and who others are and what the values and norms of the society are.

Decades after the World War II, in Turkey which had not been part of the war, children used to sing a play song when dancing. The song is about the countries that were part of the war and explains what kind of people they are. This Turkish song has catchy rhyme that makes it very easy to memorize and defines the peoples at the same time it teaches the numbers;

"One, two, three, fours: Long live Turks; four, five, six, Poland (or France) is sinking; seven, eight nine; Germany (or Hitler) is a pig. Ten, eleven, twelve; England is a fox. Thirteen, Fourteen, Fifteen; Russians are back stabbers" and so on. Like many other children, the song and the play made me think that Polish and French people are weak nations. Germans and Hitler are evil and bad. English people are not reliable. Russians are cannot be trusted and of course Turks are the best so "Long live the Turks". That is how I, as a child, used to categorize the quality of the "other" nations and my own nation. Back then, I did not know the heroic resistance movements and efforts of these peoples during the war. My perception about foreign people in my childhood world was formed, among others by this song.

A few years later, when I started the elementary school, every day, before going to the classrooms, with all my schoolmates, we had to declare our allegiance, in a very ritualistic way by shouting; "I am a Turk. I am honest and decent. I am hard working... My goal is to love my country more than my own life. Let my life become a present for the survival of the Turkish existence." In the words of the oath, constructing of my own and national self and furthermore, discrimination of other ethnic groups of Turkey can be seen. Ethnic groups other than Turks, who are also citizens and countryman of Turkey, do not exist in this nationalistic discourse. We were all raised and conditioned to think in a way that Turks were the best and were ready to die for the survival of the Turkish existence. What if a child is not an ethnic Turk? Does he/she feel excluded by this oath or does he/she prefer to think she/he is a Turk and needs to be assimilated as an adult?

One other significant memory from my childhood is a daily newspaper that used to be on the table every day. Next to the title of the daily Hurriyet, a picture of the Turkish flag appears. Underneath the flag the motto proclaims "Turkey belongs to Turks". When a child who is not an ethnic Turk sees this same motto every day, would she/he think that Turkey does not belong to her/him and feel excluded? Although, I don't know if my childhood song is still as popular these days but the national newspaper with the highest circulation in the country still enters into the many Turkish houses with the same motto on it. "Our oath" continues to be recited every day in schools by students across Turkey. When a child sees and reads the same motto every day and repeats the same words praising a certain ethnic group, cultural values and social norms, she/he believes its truthfulness without questioning and internalizes it subconsciously. Cultural and social categorizations and discriminations start developing in the mind of a child. Mind setting operates through all kinds of cultural media and socially institutionalized processes because this is the cultural policy of nationalism for perpetuating nation building.

Similar to my personal experiences, all around the world, ethnic differentiation strategies are used in order to set the minds of masses by the hegemonic powers of nationalist states. Pejorative names, humiliating proverbs, phrases with discriminatory connotations, myths, and stories, news in the media, novels in literature, framework and discourse of science all play arole at a verbal level against minorities and aliens. At the visual level, symbols, images, pictures, movies and finally and strongly television transmit messages through cultural media about "us" and the "others". These messages are full of stereotypes which insult "others" and praise "us". We learn stereotypes the same way we learn our own culture, and these stereotypes become a part of our consciousness and affect our interactions with others.

Smith (1997: 197) asserts that non-recognition policies involve the creation of alien minorities and the rise of ethnic nationalism significantly reinforces these trends. He points out to the key element of dominant ethnonationalist discrimination strategy as a "tendency of ethnic nationalisms to single out and categorize minorities within as 'alien' to the historic culture-community."Examples for this type of ethnonationalist policy can be seen, in Turkey like many other countries. For instance in the text of The Regulation of Protection against Sabotages (Sabotajlara Karşı Koruma Yönetmeligi) that was valid between the years of 1988 and 1991, some minorities were literally defined as aliens. This official text singles out some non-Muslim minority citizens of Turkey as potential saboteurs. Furthermore, the language of the text is discriminatory in which non-Muslims were defined as 'native aliens in the country' and 'those who belong to the alien race'. This is not the only example, also until 1940 non-Muslim citizens of Turkey used to be registered in the alien 
list book. ${ }^{2}$ Nowadays, similar attitudes are directed to the Kurdish minority. For example the term "internal enemy" and "so called citizen" are the terms that are often used for Kurdish citizens of Turkey by politicians and military authorities. Indeed, the term 'so called citizen' was first introduced by a chief of military staff. It later entered the lexicon. ${ }^{3}$

Smith (ibid: 198)explains how the policies of the dominant ethnic groups could harm alien minorities: "is seen as pure and authentic, non-members within are inevitably cast as counter-types and become targets of suspicion and hostility...in this circumstances they may be discriminated against, harassed, segregated and finally expelled, or even exterminated." In light of Smith's words, we can better understand how mind setting, cultural and social discrimination and politics of recognition are related to each other in racist and nationalist societies.

\subsection{Economic and Political Discrimination: Resource and Power Sharing}

All studies show that unless, relations between ethnic groups are organized based on equality without domination of any ethnic groups in society, conflict is bound to occur. In spite of being an equal citizen of the state on paper, how then economic and political discrimination emerge against minorities in contemporary societies. In order to explain this, we should take into consideration that culturally and socially constructed representations of ethnic groups operate in a society. Representation and recognition of minority ethnic groups are the key points of legitimizing and justifying inequality and discrimination both at the economic level and the political level. Culturally internalised and accepted values operate through political and economic spheres as well as the cultural sphere.

\subsubsection{Political Discrimination}

Widespread political discrimination against ethnic groups can be clearly seen in statistics. 1994-95 study of the Minorities Project Groups had found that political participation of ethnic groups is restricted. Nearly three-quarters of 275 groups experienced political discrimination in 1994-95. Due to political discrimination, three-quarters of minorities have no representation and power in policy making positions (Gurr, 2000). Cultural discrimination data of Minority Project Groups also show discrimination against ethnic groups.

More than ten years later, 2007 State of the World's Minorities Report of Minority Rights Group shows that in 50 countries among 115 different ethnic groups, 64 of minority members are under-represented in their national legislatures. More than half of minorities in 50 countries have no sufficient representation in the policy making mechanism and political participation of minorities is restricted. Among these 50 countries, 12 of them have reserved seats for some minority groups. However, as stated earlier, equality in power sharing and participation in the political sphere has a special importance and deprivation of them is one of the main causes of conflict. A cross-section-time-series regression analysis shows that the parliamentary representation has a strong ameliorative effect over ethnic conflicts(Alonso and Ruiz, 2005). "Ethnic conflicts erupt when disgruntled members of the ethnic minority engage in extra-institutional action strategies, mobilizing other group members to press the government and the state infavour of their demands" as indicated by Gurr. (2000: 349)When they get hindered in obtaining sufficient representation, they may get more hostile. Some of the examples of direct hindrance of minority groups' political participation could be seen in Bulgaria and Albania. In this countries constitutional bans prevent establishing political parties based on ethnicity. ${ }^{4}$

Beside direct hindrances, indirect hindrances can also play important roles against ethnic minority groups' political participation. Examples from Turkey could explain some type of indirect restrictions against ethnic minorities' political participation.

Under the Turkish electoral system, political parties must gain 10 percent of the national vote to enter the Parliament. This high percentage (the highest recorded by the OSCE), discriminates particularly against the pro-Kurdish parties, who are largely regionally based and have a strong support in their community, but are not able to pass this threshold. Although the pro-Kurdish political party DEHAP (Democracy Party) got more than 6 per cent of the total national vote in the general election of November 2003 (and more than 45 per cent in the five largely Kurdish provinces), they had no seats in the Parliament due to the threshold. In addition to the threshold obstacle, there are significant provisions in the Turkish law prohibiting political activities based on or demanding minority rights. Article 81 of the Political Parties Law 18 on the 'Prevention of the Creation of Minorities' prohibits political parties from claiming that

${ }^{2}$ These examples are cited from Oran, B \& A, Kaboglu. Report of Working Group on Minority Rights and Cultural Rights of Advisory Board for Prime Ministry of Turkey, September 2004.

3www.bianet.org/2005/04/14/59091.htm

${ }^{4}$ Although despite of constitutional ban Turkish minority in Bulgaria has obtained seats in Bulgarian Parliament. 
'minorities exist in the Turkish Republic'. Several political parties have been closed based on this article. The same article 81 (b) also has prohibitedfor years using language other than Turkish in political activities such as; meetings, posters, brochures or allocated campaign time in mass media as mandated by the Turkish Law. Finally, it was also widely reported when some Kurdish parliamentarians were sentenced to prison just because they read their oath in Kurdish during the inauguration ceremony of Turkish Great Assembly in1994.

\subsubsection{Economic Discrimination}

In the Minorities Project Groups 1994-95 study, it was found that equal access to economic opportunity is restricted for ethnic groups. 177 of 275 minority groups experienced some degree of economic discrimination. The discriminatory burden was greater for the 111 groups at the highest level of severity. Other statistics about income in Brazil, South Africa, and theUnited States by race can give us important data to explore the economic discrimination. In Brazil while average monthly labor income of a white male is 29,388 cruzeiros, a black male's monthly labor income is 15,578 cruzeiros which means a black male makes almost half the income of a white male. Monthly labor income for a male mulatto is 17,817 cruzeiros in Brazil, almost 15\% more than a black male and $40 \%$ less than a white male.

Similar indicators for South Africans show another picture of discrimination; while average monthly household income for white male-headed families is 6,930 rands, for black African male-headed family's monthly household income is 1,075 , that means a black African male-headed family provides $85 \%$ less income than a white family (Zoninsein, 2001 : $361,364)$ In the United States the picture is not different. For example, median income of African American families is almost \%50 lower than those of white American families (O'Connell and Birdsall, 2001: 310). In United States, Brazil and South Africa where long term discrimination has been experienced by African descendants, in spite of some special measures, economic discrimination persists. It is then more understandable why Nascimentos(2001: 119) say that "Stereotype-based discrimination is very concrete in Afro-Brazilian life, especially in the form of police repression. Blacks notoriously are "suspect"; citizens as well as African diplomats, taken for "uppity" Negroes, whose fancy car could only be stolen, have arbitrary detention." By giving this information, Nascimentos reminds us a common discriminatory result of economic discrimination, poor black is the stereotype and the fancy car owner cannot be black so he must be a thief, black citizen or the African diplomat goes to detention, of course arbitrarily. And chain of discrimination overlaps into judicial process as in any other process.

\section{Legislative Standards against Discrimination in European Union}

2007 has been designated as the "European Year of Equal Opportunities for All". The aim of the year will be to inform people of their rights; to celebrate diversity and to promote equal opportunities for everyone without discrimination in the European Union. Equal opportunities for all are only possible by a functional monitoring system and enforceable antidiscrimination legislative measures. In this regard, the EU's approach differs from that of the Council of Europe (CeO) and Organization for Security and Cooperation in Europe (OSCE). The European Union (EU) has yet not developed an instrument on minority rights. At the internal level, the emphasis is on equality and non-discrimination rather than minority rights (Pentassuglia, 2005:18). However, the EU has focused on improving the anti-discrimination legislation system hence produced two directives; one protocol to European Convention of Human Rights (ECHR) and anEuropean Commission against Racism and Intolerance (ECRI) recommendation. This process started when the EU Member States agreed in the 1999 Treaty of Amsterdam Article 13 to confer a specific legal instrument for combating racial discrimination within the framework of the EC Treaty.

\subsection{Anti-discrimination Directives of the EU}

The anti-discrimination directives of Racial Equality Directive (RED) and Equal Employment Directive (EED) are the main legal instruments of the EU for combating discrimination. Council Directive 2000/ 43/EC (RED) was adopted by the Council of Ministers of the European Union and entered into force on 19 July 2000. RED implements the principle of equal treatment of persons irrespective of racial or ethnic origin. Council Directive 2000/78/EC (EED) was also adopted and entered into force on 3 December 2000 to establish a general framework for equal treatment in employment and occupation. Other than these two directives, an action plan to combat discrimination was also planned. These three 
components came together as the "anti- discrimination package."

RED is the first piece of legislation that has to be transposed in to the national legal systems of the Member States which is seen as a pioneering legislative attempt. With its broad scope and content, Parmar (2004: 132) asserts "racial discrimination in such diverse and important areas of social life as healthcare, education and housing, in one sweep, therefore the Racial Equality Directive establishes and elevates the protection afforded to racial and ethnic origin above the other grounds of discrimination...And it is also heralds a 'new era' of equality law in Europe alongside the new Protocol 12 of ECHR"

Additionally, EED "provided protection against discrimination on grounds of religion or belief, disability, age, or sexual orientation in (self-) employment and occupation, vocational training, employment and working conditions, membership of and involvement in professional organizations." (Niessen and Chopin, 2004: 106)

Both directives in their different articles require states to take a number of measures for a successful implementation. An important change that was introduced by the directives was that the 'burden of the proof' became the responsibility of respondent. Additionally, directives require states to protect complainants from victimization or the consequences for filing a complaint. Moreover, the directives set minimum standards that are applicable across Europe. All these features of the directives strengthen combating discrimination at the legislation level.

\subsection{ECHR Protocol No.12}

On 26 June 2000, The Committee of Ministers of the Council of Europe adopted Protocol No 12 to ECHR providing a general prohibition of discrimination. Since Article 14 of the ECHR, in essence has no general and independent principle of equal treatment, ECHR protocol No 12 was produced. While article 14 prohibits discrimination only with regard to the "enjoyment of the rights and freedoms" mentioned earlier, the protocol No. 12 provides additional scope of protection in its commentary on the provisions, Article 22 as follows

i. $\quad$ in the enjoyment of any right specifically granted to an individual undernational law;

ii. in the enjoyment of a right which may be inferred from a clear obligation of a public authority under national law, that is, where public authority is under an obligation under national law to behave in a particular manner;

iii. by a public authority in the exercise of discretionary power (for example, granting certain subsidies);

iv. by any other act or omission by a public authority (for example, the behaviour of law enforcement officers when controlling a riot).

In addition to the general prohibition of discrimination, Article 1, Protocol No.12, in its operative provision, also specify the necessity of positive measures that are stated in the preamble by underscoring that "Reaffirming that the principle of nondiscrimination does not prevent States Parties from taking measures in order to promote full and effective equality, provided that there is an objective and reasonable justification for those measures..." With all these features, the protocol 12 is a useful tool on principle, and will be very useful in the future it has entered into force recently on 1 April 2005.

\subsection{ECRI Recommendation No. 7}

According to Cardinale, the European Commission against Racism and Intolerance (ECRI) drew inspiration from the Protocol 12 of the ECHR, the directives and the proposal of the EC Commission for a Council Framework Decision on Combating Racism and Xenophobia. As a result, the general policy recommendation No. 7 was prepared. Additionally, Cardinale(2004: 83) points out that the recommendation "contains the elements that ECRI considers to be key to effective national legislation against racism and racial discrimination." ECRI recommendations to the government of the EU Member States are as follows

1. "to enact legislation against racism and racial discrimination, if such legislation does not already exist or is incomplete"

2. "to ensure that the key set out below are provided in such legislation"

The recommendation explains the key elements of national legislation against racism and racial discrimination for Constitutional law, Civil and Administrative law, Criminal law, and Common provisions.In some aspects, the recommendation goes further than other instruments and includes theactivities of the police, the border control officials

5 Full texts of directives, annual reports and communications about directives are available at: http://ec.europa.eu/employment_social/fundamental_rights/public/pubst_en.htm 
and prison personnel. With this feature, itgives national specialized bodies extensive powers to combat racism and racialdiscrimination. In doing so, the recommendation applies to all public or private sector andlegal or natural persons. Additionally the Recommendation defines discrimination bydistinguishing direct and indirect discrimination and enables its implementation as unlimited. (Cardinale, 2004: 89)

\section{Implementation of Anti-Discrimination Directives and Other Legislative Instruments in Practice}

In February 2006, Ilan Halimi died soon after he was found outside of Paris half-naked, stabbed and burned with cigarettes and acid. He had been tortured and murdered because he was Jewish.In January 2007, in Istanbul, a Turkish juvenile shot and killed Hirant Dink, a well-known human rights defender in Turkey who had an Armenian ethnic background. In Belgium, May 2006, a Belgian man shot and seriously wounded a woman of Turkish origin, Songul Koc, for wearing a Muslim headscarf as she sat on a bench reading. ${ }^{6}$ All these crimes against minority members brought hundreds of thousands of people in Paris Brussels and Istanbul to protest the brutality and show solidarity with the ethnic minority groups. In Istanbul, thousands exclaimed "We are all Hrant; we are all Armenian." In spite of this show of support and solidarity, discrimination is all over Europe. This kind of discrimination which is one of the main causes of conflict is part of the same continuum of discrimination that ends in "ethnic cleansing" and genocide.

In spite of several monitoring mechanisms and legislative standards and instruments, discrimination is still common all around the world including Europe. It is a well-known fact that even if theoretically anti-discrimination rights are provided in legislation systems it is difficult to make it real for the individuals at a practical level in daily life. In order to understand the climate in which discriminatory murders and attacks occur, implementation of legislations should be examined. According to the report titled "Implementing European Anti-discrimination Law" which is published by the European Monitoring Centre on Racism and Xenophobia and Migration Policy Group, these tree countries mentioned above have problems implementing anti-discrimination measures in daily life. ${ }^{7}$ As shown below, the reasons why these events took place in these three countries are neither coincidental nor isolated. In llam's country France, findings of research indicated that "the application of antidiscrimination legislation remains very modest. The difficulty of providing proof of discriminatory conduct is very often cited to explain the weakness of the legislation. However it should also be pointed out that combating discrimination is not the prerogative of the criminal judge." (Johansson, 2004: 170)Additionally Dummett (2004: 240) reminds us how general attitudes or cultural learning negatively effects implementation of such legislation in France:

"The French dislike the idea that they could possibly be racist: racism abhorrent to them. They perceive racism much more as a matter of the spoken and the written word than as a form of behaviour. Moreover, individual complaints of unjust discrimination have usually to be made to state officials, in particular the police. Generally speaking, the most vulnerable minorities in France are exceedingly reluctant to approach the police..."

In the same research, the report on Belgium comments that "the implementation and effectiveness of this legislation is in reality deficient in several respects." (Johansson, 2004: 168)Also, three main problems with the application of the law is underscored: 1) initial filtering of complaints from victims by the police; 2) the involvement of the public prosecutor's office and 3) due to backlog of complaints and the burden of proof falling on victims, a large number of proceedings and up withdrawn. ${ }^{8}$ Johansson $(2004: 168)$ notes that "While first two problems require a change in mentality and a greater will on the part of the judiciary, the third could clearly form the subject of a legislative amendment" Third one, the problem of the burden of proof shows the importance of implementation of the directives as mentioned earlier. The Racial Equality Directive has shifted the responsibility of burden of proof to the respondent from the complaint. It is easy to amend legislations on paper but how would it be possible to change the mentality of people who are responsible for implementing these legislations. Again, Dummet (2004: 242) gives an example from a daily life practise in Belgium and shows the importance of public or private sector authorities' attitude towards the legislation in a case where "police refused to report on the facts of a car accident involving a Belgian and an alien, and 'the alien was eventually involved in violence at the police station during which he was seriously injured'. This case came to court, which found in favour of alien, who had been rendered unable to work as well as being deprived of the right to make a statement after the car accident. Behind this one brief example lies a huge problem in Belgium and elsewhere..."

\footnotetext{
${ }^{6}$ Cases are drawn from Human Rights First. Hate Crimes 2007 Survey, p.4 available at www.humanrightsfirst.org

7 Implementing European Anti-Discrimination Law- report available at: www.migpolgroup.com

${ }^{8}$ cited from the Center for Equal Opportunities and Opposition to Racism by Johhanson, Per. Ibid, p. 168
} 
Discrimination and racism has a long history and a deep legacy in today's societies therefore, changing mentalities will be long term hard work. What can be done in order to change this kind of attitude and mentality? Answers could be found in the role and activities of the civil initiatives which will be the subject of the next part. Despite all these problems, implementation of minority rights instruments and anti-discrimination legislations helped in preventing violent conflicts in the EU, particularly in countries where armed conflicts divided societies. The implementation of the minority rights protection system and anti-discrimination legislations are the first and mandatory steps. Without providing them, every effort for conflict prevention is worthless. After a long and violent period, the Irish Question in the UK and the Basque Question in Spain are now in a transition process with the implementation of the EU instruments and legislations that are welcomed by main international human rights organizations. For example, the Human Rights Watch, in its report on peace agreement, praised the effort of the UK government for implementing minority rights protection system of Europe and incorporation of the ECHR into UK Law. In the same report, Human Rights Watch (HRW) also welcomes measures to address the "pressing issues of employment equality respond to the historic legacy of discriminationagainst the Catholic minority in education, housing, and employment in Northern Ireland". Moreover, HRW commended the UK government for taking "steps to strengthen and expand anti-discrimination legislation and to combat the vast disparity in unemployment rates primarily between Catholic and Protestant men of employable age."

Additionally, in the implementation of the European anti-discrimination law research report recognizes UK's effort to use anti-discrimination legislation in a consistent way against the unlawful discrimination particularly in the employment area. Besides that, the report emphasizes the role of implementing the legislation and protecting minority rights to prevent conflict in Northern Ireland as follows;" The direct connection between discrimination on ground of religion or belief and the long political conflict in Northern Ireland has yielded both stronger anti-discrimination legislation and a more active, positive, involvement by government."(Johansson; 2004: 177)

As a matter of fact, the UK has had a Race Relation Act since 1965 which did not go far enough but the 1976 act that was amended in 2000 produced positive effects in general. Unfortunately, despite the act, Northern Ireland had been treated differently in many respects from the UK as emphasized by Dummett (2004: 242). As a result, available legislation did not help in preventing conflict between the Catholics and the Protestants in Northern Ireland. After updating its legislation and the minority protection system in accordance with the EU system, the UK became one of the most successful executive and beneficiary of the system. We should remind that this impressive achievement is not only the result of governments' effort; as a matter of fact civil society and their mass mobilized campaigns enforced the governments to reconsider the demands of the people and change their policies. Therefore, it can be said that any achievement in this field is only possible when public authorities cooperate with civil societies. Without the civil society enforcement, governments and dominant powers of societies would not volunteer to change the power relation that protects their interests in the society.

\section{Conclusion}

It is obvious that today there is more legislation; there are more institutional initiatives and a growing awareness of the need to overcome discrimination than ever. On the other hand, from race, ethnic background, to gender, age at work, at streets, at public sphere discrimination is everywhere. Furthermore, the agenda of discrimination is diversifying, and new challenges arise where old ones remain at best only partially answered as it is said by International Labor Organization (ILO). ${ }^{10}$ Worries about rising racism and discriminatory practices and attitudes of the European and non-European governments can be overcome with the help of legislative measures.

In conclusion, consistent political will and the support of civil society could help to the countries in creating a democratic, pluralist and multiethnic society in which all groups are integrated equally without discrimination. Integrating diversity and providing effective legislative standards against discrimination and implementation of the system will help to the societies in overcoming its social conflicts and will enable the development of peaceful and stable societies.

\section{References}

Alonso, S\& R. Ruiz. (2005) "Political Representation and Ethnic Conflict in New Democracies." Discussion Papers SP IV $2005-201$. Berlin: Wissenschaftszentrum Berlin fur Sozialforschung (WZB)

${ }^{9}$ Human Rights Watch Report ' Justice for All: An Analysis of the Human Rights Provisions of the 1998Northern Ireland Peace Agreement' 1998 Vol. 10, no. 3 (D)

10Available at: (11 11 2013) at: http://www.ilo.org/declaration/Follow-up/Globalreports/lang--en/index.htm 
Brown, Roger. (1986) Social Psychology. (2.nd ed) New York: Free Press, p. 533

Cardinale, Giancarlo (2004) The Preparation of ECRI General Policy Recommendation No 7. In Niessen\&Chopin (eds) The Development of Legal Instruments to Combat Racism in a Diverse Europe. The Hauge: MartinusNijhoff Publisher

Dummet, Ann. (2004) Implementing European Anti-Discrimination Law, in Niessen\& Chopin (eds) The Development of Legal Instruments to Combat Racism in a Diverse Europe. The Hauge: MartinusNijhoffPublisher

Fraser, Nancy. (1998) "Social Justice in the Age of Identity Politics: Redistribution, Recognition, Participation" Discussion Paper FS I 98 -10 Berlin

Gurr, Ted Robert.(2000) Minorities at Risk: A Global View of Ethno political Conflicts. Washington D.C.: United States Institute of Peace Press

Johansson, Per. (2004) Comparing National and Community Anti-Discrimination Law, inNiessen\& Chopin (eds) The Development of Legal Instruments to Combat Racism in a Diverse Europe. The Hauge: MartinusNijhoff Publisher

Nascimento, A \& E. L Nascimento, (2001) Dance of Deception: A Reading of Race Relations in Brazil". Pp. 105-157. In (eds) Hamilton \& Huntley. Beyond Racism: Race and Inequality in Brazil, South Africa, And The United States. p. 89

Niessen\& Chopin. (2004)The Starting Line and the Racial Equality Directive.inNiessen\& Chopin (eds) TheDevelopment of Legal Instruments to Combat Racism in a Diverse Europe. The Hauge: MartinusNijhoff Publisher.

O'Connell, L \& N, Birdsall.(2001) Race, Human Capital Inequality, and Income Distribution. In: Beyond Racism. (eds) Hamilton \& Huntley. London: Lynne Rienner Publishers. P. 310

Parmar, Sejal. (2004) The European Court of Justice and Anti-discrimination Law.inNiessen\& Chopin (eds) The Development of Legal Instruments to Combat Racism in a Diverse Europe. The Hauge: Martinus Nijhoff Publisher.

Pentassuglia,Gaetano. (2005) Introduction in Morawa\& Keller Mechanisms for implementation of Minority Rights.Council of Europe Publishing.

Smith, Anthony D. (1997) Myths and Memories of the Nation. New York: Oxford University Press

Taylor, Charles. (1994) The Politics of Recognition in Multiculturalism: Examining the politics of recognition. (ed) Amy, Gutman. New Jersey: Princeton University Press

UNESCO. (1999) UNESCO and Human Rights: Standard Setting Instruments Major Meetings Publications. Paris: United Nations Educational, Scientific and Cultural Organization.

Zoninsein, Jonas. GDP Increases from Ending Long-Term Discrimination against Blacks. In: Beyond Racism (eds) Hamilton \& Huntley. London: Lynne Rienner Publishers. 
